\title{
Article \\ Beneficial Soil Fungi and Jabuticaba Growth Promotion
}

\author{
Maira Nascimento Batistello ${ }^{1}$, Nayane Fonseca Brito ${ }^{1}$, Willian Nogueira de Sousa ${ }^{2}{ }^{\mathbb{D}}$, \\ Cristina Aledi Felsemburgh ${ }^{1}$, Thiago Almeida Vieira ${ }^{1}\left[\begin{array}{l}\text { (D) } \\ \text { and Denise Castro Lustosa }\end{array}\right.$ \\ 1 Institute of Biodiversity and Forests, Federal University of Western Pará, Santarém 68040-255, Brazil; \\ mairasbatistello@gmail.com (M.N.B.); nayanebrito4@gmail.com (N.F.B.); crisalefel@gmail.com (C.A.F.); \\ thiago.vieira@ufopa.edu.br (T.A.V.) \\ 2 Altamira City Hall, Altamira 68371-456, Brazil; wnsagro@gmail.com \\ * Correspondence: denise.lustosa@ufopa.edu.br
}

check for updates

Citation: Batistello, M.N.; Brito, N.F.; de Sousa, W.N.; Felsemburgh, C.A.; Vieira, T.A.; Lustosa, D.C. Beneficial Soil Fungi and Jabuticaba Growth Promotion. Agronomy 2022, 12, 367. https://doi.org/10.3390/ agronomy12020367

Academic Editors: Jorge M. S. Faria, Clarisse Brigido and Esther Menéndez

Received: 27 December 2021

Accepted: 28 January 2022

Published: 31 January 2022

Publisher's Note: MDPI stays neutral with regard to jurisdictional claims in published maps and institutional affiliations.

Copyright: (C) 2022 by the authors. Licensee MDPI, Basel, Switzerland. This article is an open access article distributed under the terms and conditions of the Creative Commons Attribution (CC BY) license (https:// creativecommons.org/licenses/by/ $4.0 /)$.

\begin{abstract}
Trichoderma is a genus of fungi widely used in agriculture as a biocontrol agent and more recently as a plant growth promoter. We evaluated five Trichoderma isolates, in different application modes, throughout the development of jabuticaba seedlings. These included three isolates of the species Trichoderma asperellum (Tam01, Tam02, and Tam03) and two isolates of Trichoderma sp. (Tc and Tce) in four modes of application: via seeds; in applications on the pre-planting substrate; in monthly applications in the post-planting substrate; and their combination. The control treatment consisted of plants without the use of Trichoderma. Seedling height, collar diameter, and the number of leaves were evaluated monthly. Statistical analysis was conducted using data collected two, four, seven, and thirteen months after emergence. The application of Trichoderma promoted the growth of jabuticaba seedlings up to four months after emergence. The isolate Tam03 and the application via seeds were the treatments that most influenced the analyzed variables at four months. The use of Trichoderma stimulated the beginning of the development of jabuticaba seedlings.
\end{abstract}

Keywords: biostimulant; Myrciaria cauliflora; seedling production; sustainable agriculture

\section{Introduction}

The production of fruit plants can have several obstacles, such as implantation and maintenance costs, inadequate management of the plant, water and soil, in addition to phytosanitary problems that limit the attainment of quality seedlings. Many phytopathogens attack fruit species and the application of chemical products is still the most used method to control plant diseases and, if used wrongly or abusively, it can cause several problems, such as developing resistance to pathogens, causing biological imbalance, contaminating the soil and water and even the applicators themselves, in addition to the final consumer of the products. Thus, other control options can be used, such as the application of biocontrol agents [1] and the choice of resistant plants for integrated disease management programs.

The use of beneficial microorganisms, such as Trichoderma, can be applied to stimulate the development of seedlings. In addition to acting as disease control agents in several cultivated species, fungi of this genus are capable of promoting growth and inducing plant resistance to diseases [2-7] and resistance to salinity [8], with great environmental and economic importance for agriculture.

Trichoderma asperellum UFT 201 increased the dry mass of the aerial shoot of cowpea $(84 \%)$, soybean $(128 \%)$, rice $(95 \%)$, and corn $(78 \%)$ [9]. This genus of fungi increased the dry weight of sugarcane leaf [2], 30\% in dry matter production of bean plants [10], and up to a $100 \%$ increase in the growth of cucumber plants [11]. The application of Trichoderma in tree species has already been studied to verify its effects on germination and growth promotion, with promising results [3-5,12,13].

The growth promotion in plants caused by microorganisms may be related to the production of gibberellins that are translocated from the roots to the aerial part [14]. The 
production of auxins, cytokinins, and other metabolites by Trichoderma that promote plant growth and help in the stages of cell division has already been reported [15-17], in addition to phosphate solubilization [18].

In fruit trees, Trichoderma can be used to improve germination, promote growth, and reduce the length of stay in the nursery, as in the case of jabuticaba, which has a slow growth and can take up to 10 years for the first production, when it is not hybrid [19]. This species can benefit from the application of Trichoderma in the production of seedlings.

The jabuticaba (Myrciaria cauliflora Berg.) is native to Brazil, belongs to the botanical family Myrtaceae, and has spontaneous occurrence in a large part of the country [20]. The states of southeastern Brazil, in the Atlantic Forest Biome, present the highest production [21]. The plants can reach $20 \mathrm{~m}$ in height, have lanceolate to oblong-lanceolate leaves, and have globose berry fruits with a red to black bark color when ripe [22]. The species has several food uses, such as fresh consumption or in the form of jellies; the fermented pulp produces liquor, wine and vinegar, juices, jellies, jams, liqueurs, and brandies [23,24].

The jabuticaba fruit is rich in iron, calcium, phosphorus, vitamins B and C [25], and antioxidant bioactive compounds [24,26,27], which have the function of preventing skin problems, rheumatism, and hair loss [25], also presenting antimicrobial activity [26,28]. This species has many health benefits, such as balancing cholesterol levels and blood pressure; acting as an anti-inflammatory; collaborating with the structures of the brain, namely the hippocampus, which is linked to the regulation and preservation of memory, and studies are being developed using the bark extract against the progression of prostate cancer [19]. Industrial process characteristics, such as temperature and pressure, influence the percentage of antioxidant compounds in the extract and production costs [29]. Thus, jabuticaba can generate products that meet the industrial demands for natural additives that can be beneficial to health and for new sources of natural pigments at a low cost to consumers [26].

Despite all of the benefits reported for the species, the search for methods that contribute to the production of quality seedlings is essential in plant production to bring vigorous and resistant plants to the field and to contribute to the market niche of this fruit tree. The propagation of the species occurs by sexual or asexual means. Studies that incorporate sustainable-based treatments, such as biostimulant microorganisms, are important to improve the production of jabuticaba seedlings. Thus, in this research, the effects of five Trichoderma isolates, applied in different ways, on the development of jabuticaba seedlings were evaluated.

\section{Materials and Methods}

\subsection{Study Conditions and Location}

The experiment started in December 2018 and ended in March 2020 in the nursery of the Institute of Biodiversity and Forests of the Federal University of Western Pará, Ufopa, in the city of Santarém, Brazilian Amazonia. The climate of the region is of the Am type (Köppen classification), with total annual rainfall ranging from $2000 \mathrm{~mm}$ to $2500 \mathrm{~mm}$, and approximately $80 \%$ of the annual rainfall occurs from December to May [30]. The research was registered in the National System for the Management of Genetic Heritage and Associated Traditional Knowledge (SISGEN) under protocol A67256B.

\subsection{Obtaining Jabuticaba Seeds and Trichoderma Isolates}

The jabuticaba seeds were collected from five seven-year-old mother trees showing no symptoms of disease in agroforestry backyards located in the rural community of Agrovila Tiradentes, a municipality of Medicilândia in state of Pará, Brazil, under coordinates $3^{\circ} 29^{\prime} 27.8^{\prime \prime} \mathrm{S} 52^{\circ} 47^{\prime} 10.0^{\prime \prime} \mathrm{W}$. In the laboratory, the seeds were manually extracted from the fruits with the aid of a sieve, followed by washing in running water. The seeds were disinfected for $3 \mathrm{~min}$ in $2 \%$ sodium hypochlorite $(\mathrm{NaOCl})$ solution.

Trichoderma spp. were isolated from soils of the Amazon region, according to Alfenas and Mafia [31], with three belonging to the species Trichoderma asperellum (Tam01, Tam02, 
and Tam03) and two from Trichoderma sp. (Tc and Tc). These fungal isolates are deposited in the Micoteca of the Phytopathology Laboratory in Ufopa.

For inoculation of Trichoderma spp. in seeds and seedlings, the mass production of the fungi in parboiled rice was made and stored under refrigeration until the preparation of the suspensions for use in the trial [3,5].

\subsection{Trichoderma spp. in the Initial Development of Jabuticaba Seedlings}

Biological agents (Tam01, Tam02, Tam03, Tc, and Tce) were tested by the following application modes: (a) via seeds; (b) in the pre-planting substrate; (c) monthly in the postplanting substrate; $(d)$ in their triple combination: seed + pre-planting substrate + monthly in post-planting substrate. The control treatment consisted of plants immersed in water without the use of Trichoderma.

The sowing was performed in polyethylene bags with $1.5 \mathrm{~kg}$ of forest soil. Soil $\mathrm{pH}$ was 6.26, determined in a 1:2.5 soil:water $(w / v)$ suspension. The concentration of $P$ was $158.9 \mathrm{mg} \cdot \mathrm{kg}^{-1}$ and $\mathrm{K} 4.5 \mathrm{cmolc} \cdot \mathrm{kg}^{-1}$, obtained by Mehlich-1 extracting solution. The exchangeable elements $\left(\mathrm{Ca}=5.3 \mathrm{cmolc} \cdot \mathrm{kg}^{-1} ; \mathrm{Mg}=1.3 \mathrm{cmolc} \cdot \mathrm{kg}^{-1} ; \mathrm{Al}=0.74 \mathrm{cmolc} \cdot \mathrm{kg}^{-1}\right)$ were determined by KCL Extractor $1 \mathrm{~mol} \cdot \mathrm{L}^{-1}$. Throughout the evaluation period, the seedlings were cultivated under a nursery with $50 \%$ shading. Daily, each seedling was irrigated with $100 \mathrm{~mL}$ of water. No nutrients were applied during the experiment.

Suspensions were prepared with each Trichoderma isolate $\left(1 \times 10^{8}\right.$ conidia $\left.\cdot \mathrm{mL}^{-1}\right)$. For treatments using seed fungus application, we immersed it in Trichoderma suspensions for $24 \mathrm{~h}$ before planting. When using Trichoderma spp. in the substrate, we proceeded in two ways: pre-planting, $10 \mathrm{~mL}$ of suspension were applied seven days before planting; in post-planting treatments, $10 \mathrm{~mL}$ of fungi suspension were applied monthly.

Thirty days after emergence, in the post-planting treatments, we started the monthly applications of Trichoderma isolates. In the combined treatment, we applied Trichoderma spp. in seeds + one application in the substrate pre-planting + monthly applications in the substrate post-planting, following the same methodology adopted for each of the application modes. Thirteen applications of Trichoderma isolates were performed in treatments that received monthly applications in the post-planting subtract (alone and in the combination of the three modes of application).

The trial was set up in a completely randomized design (DIC), in a factorial scheme $(4 \times 5+1)$, with four application modes $\times$ five Trichoderma isolates + a control treatment, and with 10 replications (one plant per repetition). The variables were evaluated monthly, as follows: (a) height, by measuring from the base of the collar to the apex of the stem, with the aid of a millimeter ruler; (b) collar diameter, measured in the region of the base of the plant, using a digital caliper; (c) number of leaves, by directly counting the total number of leaves in each seedling.

\subsection{Statistical Analysis}

ANOVA was performed using data obtained at two, four, seven, and thirteen months after emergence. First, to compare the means of all treatments with the control, we used the Dunnett test $(p \leq 0.05)$ and the Tukey test $(p \leq 0.05)$ to compare the means of the treatments with each other by using the software Assistat ${ }^{\circledR} 7.7$ [32].

\section{Results}

Emergence began 14 days after sowing, with stabilization 20 days after planting. Two months after emergence, there was a significant difference between treatments and control for the height and number of leaves. For height, six treatments differed from the control, causing a greater increase in this variable, three with the application of the isolate T. asperellum Tam03 (Table 1). The increments in the height varied from $21 \%$ to $28.1 \%$ in relation to the control. The number of leaves was higher, compared to the control, for three of the 20 treatments evaluated during this period (Table 1). 
Table 1. Height, collar diameter, and number of leaves of jabuticaba (Myrciaria cauliflora) seedlings submitted to different application modes of Trichoderma spp. isolates, two months after emergence.

\begin{tabular}{lccc}
\hline \multicolumn{1}{c}{ Treatments } & $\begin{array}{c}\text { Height } \\
(\mathbf{c m})\end{array}$ & $\begin{array}{c}\text { Collar } \\
\text { Diameter (cm) }\end{array}$ & $\begin{array}{c}\text { Number } \\
\text { of Leaves }\end{array}$ \\
\hline Tam01 applied to seeds & $6.2^{\mathrm{ns}}$ & $0.6^{\mathrm{ns}}$ & $5.4^{\mathrm{ns}}$ \\
Tam01 applied to pre-planting substrate & $6.7^{\mathrm{ns}}$ & $0.7^{\mathrm{ns}}$ & $6.4^{\mathrm{ns}}$ \\
Tam01 applied monthly to post-planting substrate & $6.7^{\mathrm{ns}}$ & $0.7^{\mathrm{ns}}$ & $6.1^{\mathrm{ns}}$ \\
Tam01 seeds + substrate + monthly & $6.3^{\mathrm{ns}}$ & $0.6^{\mathrm{ns}}$ & $6.2^{\mathrm{ns}}$ \\
Tam02 applied to seeds & $6.9^{*}$ & $0.6^{\mathrm{ns}}$ & $5.7^{\mathrm{ns}}$ \\
Tam02 applied to pre-planting substrate & $5.8^{\mathrm{ns}}$ & $0.6^{\mathrm{ns}}$ & $5.6^{\mathrm{ns}}$ \\
Tam02 applied monthly to post-planting substrate & $6.1^{\mathrm{ns}}$ & $0.8^{\mathrm{ns}}$ & $6.2^{\mathrm{ns}}$ \\
Tam02 seeds + substrate + monthly & $6.5^{\mathrm{ns}}$ & $0.6^{\mathrm{ns}}$ & $6.3^{\mathrm{ns}}$ \\
Tam03 applied to seeds & $7.0^{*}$ & $0.7^{\mathrm{ns}}$ & $6.0^{\mathrm{ns}}$ \\
Tam03 applied to pre-planting substrate & $6.6^{\mathrm{ns}}$ & $0.8^{\mathrm{ns}}$ & $5.8^{\mathrm{ns}}$ \\
Tam03 applied monthly to post-planting substrate & $7.3^{*}$ & $0.7^{\mathrm{ns}}$ & $6.8^{*}$ \\
Tam03 seeds + substrate + monthly & $7.3^{*}$ & $0.8^{\mathrm{ns}}$ & $7.4^{*}$ \\
Tc applied to seeds & $7.0^{*}$ & $0.7^{\mathrm{ns}}$ & $6.8^{*}$ \\
Tc applied to pre-planting substrate & $5.6^{\mathrm{ns}}$ & $0.6^{\mathrm{ns}}$ & $5.5^{\mathrm{ns}}$ \\
Tc applied monthly to post-planting substrate & $6.2^{\mathrm{ns}}$ & $0.6^{\mathrm{ns}}$ & $6.0^{\mathrm{ns}}$ \\
Tc seeds + substrate + monthly & $7.0^{*}$ & $0.7^{\mathrm{ns}}$ & $6.6^{\mathrm{ns}}$ \\
Tce applied to seeds & $6.1^{\mathrm{ns}}$ & $0.7^{\mathrm{ns}}$ & $5.2^{\mathrm{ns}}$ \\
Tce applied to pre-planting substrate & $6.3^{\mathrm{ns}}$ & $0.7^{\mathrm{ns}}$ & $6.1^{\mathrm{ns}}$ \\
Tce applied monthly to post-planting substrate & $6.5^{\mathrm{ns}}$ & $0.8^{\mathrm{ns}}$ & $5.7^{\mathrm{ns}}$ \\
Tce seeds + substrate + monthly & $6.4^{\mathrm{ns}}$ & $0.8^{\mathrm{ns}}$ & $5.8^{\mathrm{ns}}$ \\
Control & $5.7^{\mathrm{ns}}$ & $0.6^{\mathrm{ns}}$ & $4.5^{\mathrm{ns}}$ \\
\hline
\end{tabular}

* Significant; ns, not significant; by Dunnett test $(p<0.05)$. Tc, Trichoderma sp.; Tce $=$ Trichoderma sp.; Tam01 $=$ Trichoderma asperellum; Tam02 $=$ Trichoderma asperellum; Tam03 $=$ Trichoderma asperellum .

The use of T. asperellum Tam03 increased the number of leaves, when compared to the control, in two treatments: monthly in the post-planting substrate $(51.1 \%)$ and in the triple combination (64.4\%). The Trichoderma sp. Tc applied via seeds also provided a greater number of leaves in jabuticaba seedlings, with an increase of $51.1 \%$, compared to the control.

Regarding the Tukey test, there was a significant difference for the application modes factor in the collar diameter, as well as for the interaction between the factors (application modes $\times$ Trichoderma isolates) for the height and collar diameter (Table 2). There was no significant difference between treatments for the number of leaves at two months.

Table 2. Height and collar diameter of jabuticaba (Myrciaria cauliflora) plants subjected to different application modes of five Trichoderma spp. isolates two months after emergence.

\begin{tabular}{|c|c|c|c|c|c|c|c|c|c|c|}
\hline \multirow{3}{*}{$\begin{array}{c}\text { Application } \\
\text { Modes }\end{array}$} & \multicolumn{10}{|c|}{ Trichoderma Isolates } \\
\hline & Tam01 & Tam02 & Tam03 & Tc & Tce & Tam01 & Tam02 & Tam03 & Tc & Tce \\
\hline & \multicolumn{5}{|c|}{ Height (cm) } & \multicolumn{5}{|c|}{ Collar Diameter (cm) } \\
\hline Seeds ${ }^{1}$ & $6.2 \mathrm{bcA}$ & $6.7 \mathrm{abA}$ & $6.7 \mathrm{aA}$ & $6.3 \mathrm{abA}$ & $7.0 \mathrm{aA}$ & $0.7 \mathrm{abA}$ & $0.7 \mathrm{aA}$ & $0.8 \mathrm{aA}$ & $0.6 \mathrm{bA}$ & $0.7 \mathrm{abA}$ \\
\hline Substrate $^{2}$ & $5.8 \mathrm{cB}$ & $6.1 \mathrm{bAB}$ & $6.5 \mathrm{aAB}$ & $7.0 \mathrm{aA}$ & $6.5 \mathrm{aAB}$ & $0.6 \mathrm{bA}$ & $0.7 \mathrm{aA}$ & $0.6 \mathrm{aA}$ & $0.7 \mathrm{abA}$ & $0.7 \mathrm{abA}$ \\
\hline Monthly ${ }^{3}$ & $7.3 \mathrm{aA}$ & $7.3 \mathrm{aA}$ & $7.0 \mathrm{aAB}$ & $5.5 \mathrm{bC}$ & $6.2 \mathrm{aBC}$ & $0.7 \mathrm{abAB}$ & $0.8 \mathrm{aA}$ & $0.7 \mathrm{aAB}$ & $0.6 \mathrm{abB}$ & $0.6 \mathrm{bB}$ \\
\hline Combination 4 & $7.0 \mathrm{abA}$ & $6.1 \mathrm{bA}$ & $6.3 \mathrm{aA}$ & $6.5 \mathrm{aA}$ & $6.4 \mathrm{aA}$ & $0.8 \mathrm{aA}$ & $0.7 \mathrm{aA}$ & $0.7 \mathrm{aA}$ & $0.7 \mathrm{aA}$ & $0.8 \mathrm{aA}$ \\
\hline
\end{tabular}

Coefficient of Variation $(\%)=12.7$

Coefficient of Variation $(\%)=19.9$

Means followed by the same lowercase letters in the columns and the capital letters in the rows do not differ according to Tukey's test $(p \leq 0.05) .{ }^{1}=$ Trichoderma isolates on seeds; ${ }^{2}=$ Trichoderma isolates in the pre-planting substrate; ${ }^{3}=$ monthly using of Trichoderma isolates in the post-planting substrate; ${ }^{4}=$ Trichoderma applied seeds + application in the substrate at pre-planting + monthly application in the substrate post-planting.

When the five Trichoderma isolates were compared in the same mode of application, for the height of the plants, it was observed that seedling-treated T. asperellum Tam01 via seeds showed the smallest height, while, in the mode of monthly application in the substrate 
after planting, the lowest height was observed in seedlings that received the application of Trichoderma sp. Tc (Table 2).

For the collar diameter of jabuticaba seedlings, the behavior of all Trichoderma isolates in the same mode of application, two months after emergence, there was only a significant difference between the fungi used in monthly applications in the post-planting substrate, with T. asperellum Tam02 differing from Trichoderma sp. Tc and Tc. Monthly applications of Trichoderma sp. Tc and Trichoderma sp. Tce resulted in seedlings with a smaller collar diameter compared to T. asperellum Tam02 (Table 2), with a $25 \%$ reduction.

When comparing each Trichoderma isolate separately in the four application modes, it was observed that T. asperellum Tam01 used in a triple combination favored the increase in the collar diameter in relation to its application only in the pre-planting substrate (Table 2).

Four months after emergence, a significant difference was observed between treatments and control in all analyzed variables (Table 3). Six treatments increased the height of the seedlings, 15 increased the collar diameter, and 18 positively influenced the number of leaves. Of the treatments that differed from the control, 11 were with the application of Trichoderma isolates in the seeds; 10 with the monthly applications in the post-planting substrate and in the combination of treatments (on seeds, on pre-planting substrate, and monthly applications in the post-planting), and seven in the application only in the preplanting substrate (Table 3 ).

Table 3. Height, collar diameter, and number of leaves of jabuticaba (Myrciaria cauliflora) seedlings submitted to different application modes of Trichoderma spp. isolates, four months after emergence.

\begin{tabular}{lccc}
\hline \multicolumn{1}{c}{ Treatments } & $\begin{array}{c}\text { Height } \\
(\mathbf{c m})\end{array}$ & $\begin{array}{c}\text { Collar } \\
\text { Diameter (cm) }\end{array}$ & $\begin{array}{c}\text { Number } \\
\text { of Leaves }\end{array}$ \\
\hline Tam01 applied to seeds & $9.0^{*}$ & $1.1^{*}$ & $13.0^{*}$ \\
Tam01 applied to pre-planting substrate & $9.3^{*}$ & $1.2^{*}$ & $12.3^{*}$ \\
Tam01 applied monthly to post-planting substrate & $8.8^{\mathrm{ns}}$ & $1.1^{*}$ & $12.8^{*}$ \\
Tam01 seeds + substrate + monthly & $7.9^{\mathrm{ns}}$ & $1.0^{*}$ & $12.3^{*}$ \\
Tam02 applied to seeds & $8.6^{\mathrm{ns}}$ & $0.9^{\mathrm{ns}}$ & $12.5^{*}$ \\
Tam02 applied to pre-planting substrate & $7.9^{\mathrm{ns}}$ & $0.9^{\mathrm{ns}}$ & $10.3^{\mathrm{ns}}$ \\
Tam02 applied monthly to post-planting substrate & $7.6^{\mathrm{ns}}$ & $1.0^{*}$ & $11.6^{*}$ \\
Tam02 seeds + substrate + monthly & $8.8^{\mathrm{ns}}$ & $1.0^{*}$ & $10.9^{*}$ \\
Tam03 applied to seeds & $9.4^{*}$ & $1.1^{*}$ & $13.8^{*}$ \\
Tam03 applied to pre-planting substrate & $8.6^{\mathrm{ns}}$ & $1.0^{*}$ & $11.2^{*}$ \\
Tam03 applied monthly to post-planting substrate & $10.2^{*}$ & $1.1^{*}$ & $14.0^{*}$ \\
Tam03 seeds + substrate + monthly & $9.4^{*}$ & $1.2^{*}$ & $12.5^{*}$ \\
Tc applied to seeds & $8.6^{\mathrm{ns}}$ & $1.2^{*}$ & $13.3^{*}$ \\
Tc applied to pre-planting substrate & $7.1^{\mathrm{ns}}$ & $0.8^{\mathrm{ns}}$ & $9.4^{\mathrm{ns}}$ \\
Tc applied monthly to post-planting substrate & $8.0^{\mathrm{ns}}$ & $0.9^{\mathrm{ns}}$ & $12.8^{*}$ \\
Tc seeds + substrate + monthly & $9.2^{*}$ & $0.9^{\mathrm{ns}}$ & $12.3^{*}$ \\
Tce applied to seeds & $8.4^{\mathrm{ns}}$ & $1.1^{*}$ & $12.2^{*}$ \\
Tce applied to pre-planting substrate & $7.8^{\mathrm{ns}}$ & $1.0^{*}$ & $12.0^{*}$ \\
Tce applied monthly to post-planting substrate & $8.0^{\mathrm{ns}}$ & $1.0^{*}$ & $11.8^{*}$ \\
Tce seeds + substrate + monthly & $8.3^{\mathrm{ns}}$ & $1.1^{*}$ & $11.4^{*}$ \\
Control & $7.4^{\mathrm{ns}}$ & $0.8^{*}$ & $5.8^{*}$ \\
\hline
\end{tabular}

* Significant; ${ }^{\text {ns }}$, not significant; by Dunnett test $(p<0.05)$. Tc, Trichoderma sp.; Tce = Trichoderma sp.; Tam01 = Trichoderma asperellum; Tam02 = Trichoderma asperellum; Tam03 = Trichoderma asperellum .

Of the four treatments that used the isolate T. asperellum Tam03, three increased height and all increased collar diameter and number of leaves. For T. asperellum Tam01, two treatments increased height, and four increased collar diameter and number of leaves. For Trichoderma sp. Tce, all four treatments increased collar diameter and number of leaves of jabuticaba seedlings (Table 3).

The evaluation after four months showed six treatments that increased the height of the plants when compared to the control, two with the application of T. asperellum Tam01 (seeds and substrate pre-planting), three with the use of Trichoderma Tam03 (seeds; monthly 
applications and in the triple combination), and one with the application of the fungal isolate Trichoderma sp. Tc, in the combination of the three application modes (Table 3).

Height increases caused by these treatments ranged from $21.6 \%$ to $35.1 \%$ in relation to the control. For the collar diameter evaluated at four months, 15 of the 20 treatments tested differed from the control, increasing this variable. The increments in collar diameter provided by Trichoderma isolates ranged from $25 \%$ to $50 \%$. Regarding the number of leaves observed at four months, the increase ranged from $79.3 \%$ to $141.4 \%$.

Four months after emergence, significant differences were also observed between treatments for the interaction between factors in the height and collar diameter (Table 4). For the height, when Trichoderma isolates were applied in the pre-planting substrate, there was only a significant difference between T. asperellum Tam02 and Trichoderma sp. Tc, with Tc causing a greater increase in height. When T. asperellum Tam01 was used in monthly applications in the post-planting substrate, it caused a greater increase in height compared to Tam03, Tce, and Tc (Table 4).

Table 4. Height and collar diameter of jabuticaba (Myrciaria cauliflora) plants subjected to different application modes of five Trichoderma spp. isolates four months after emergence.

\begin{tabular}{|c|c|c|c|c|c|c|c|c|c|c|}
\hline \multirow{3}{*}{$\begin{array}{c}\text { Application } \\
\text { Modes }\end{array}$} & \multicolumn{10}{|c|}{ Trichoderma Isolates } \\
\hline & Tam01 & Tam02 & Tam03 & Tc & Tce & Tam01 & Tam02 & Tam03 & Tc & Tce \\
\hline & \multicolumn{5}{|c|}{ Height (cm) } & \multicolumn{5}{|c|}{ Collar Diameter (cm) } \\
\hline Seeds 1 & $9.0 \mathrm{abA}$ & $9.3 \mathrm{aA}$ & $8.8 \mathrm{aA}$ & $7.9 \mathrm{bA}$ & $8.6 \mathrm{aA}$ & $1.1 \mathrm{abA}$ & $1.2 \mathrm{aA}$ & $1.1 \mathrm{aA}$ & $1.0 \mathrm{aA}$ & $0.9 \mathrm{aA}$ \\
\hline Substrate $^{2}$ & $7.9 \mathrm{bAB}$ & $7.6 \mathrm{bB}$ & $8.8 \mathrm{aAB}$ & $9.4 \mathrm{aA}$ & $8.6 \mathrm{aAB}$ & $0.9 \mathrm{bB}$ & $1.0 \mathrm{aAB}$ & $1.0 \mathrm{aAB}$ & $1.1 \mathrm{aA}$ & $1.0 \mathrm{aAB}$ \\
\hline Monthly $^{3}$ & $10.2 \mathrm{aA}$ & $9.4 \mathrm{aAB}$ & $8.6 \mathrm{aBC}$ & $7.1 \mathrm{bC}$ & $8.0 \mathrm{aBC}$ & $1.1 \mathrm{aA}$ & $1.2 \mathrm{aA}$ & $1.2 \mathrm{aA}$ & $0.8 \mathrm{bB}$ & $0.9 \mathrm{aB}$ \\
\hline Combination ${ }^{4}$ & $9.2 \mathrm{abA}$ & $8.4 \mathrm{abA}$ & $7.8 \mathrm{aA}$ & $8.3 \mathrm{abA}$ & $8.3 \mathrm{aA}$ & $0.9 \mathrm{abA}$ & $1.1 \mathrm{aA}$ & $1.0 \mathrm{aA}$ & $1.0 \mathrm{aA}$ & $1.1 \mathrm{aA}$ \\
\hline
\end{tabular}

Means followed by the same lowercase letters in the columns and the capital letters in the rows do not differ according to Tukey's test $(p \leq 0.05) .{ }^{1}=$ Trichoderma isolates on seeds; ${ }^{2}=$ Trichoderma isolates in the pre-planting substrate; ${ }^{3}=$ monthly using of Trichoderma isolates in the post-planting substrate; ${ }^{4}=$ Trichoderma applied seeds + application in the substrate at pre-planting + monthly application in the substrate post-planting.

At four months after emergence, the interaction of factors (Trichoderma versus application modes) showed that, for the collar diameter, T. asperellum Tam01 $(0.9 \mathrm{~cm})$ differed significantly from Trichoderma sp. Tc $(1.1 \mathrm{~cm})$ when applied to the pre-planting substrate. Jabuticaba seedlings treated with the T. asperellum isolates (Tam01, Tam02, and Tam03), monthly in the post-planting substrate showed greater increases in relation to Trichoderma sp. Tc and Tce (Table 4).

At seven months after emergence, there was no significant difference between treatments and controls for height, collar diameter, and number of leaves. Significant differences were observed only between treatments for the application mode factor in the three variables analyzed. The applications of Trichoderma isolates in seeds and monthly in the post-planting substrate caused the greatest increase in height in relation to the combined treatments (Figure 1). For the collar diameter of jabuticaba seedlings, seven months after emergence, there was only a significant difference between the monthly application of Trichoderma isolates in the post-planting substrate and the combined treatments. Monthly applications promoted a greater increase in the collar diameter compared to the combined treatment (Figure 1).

The effect of the application modes on the number of leaves was similar to that found for the collar diameter in the same period, with a significant difference only between the monthly applications of Trichoderma in the post-planting substrate and the combination of the three application modes (Figure 1). 

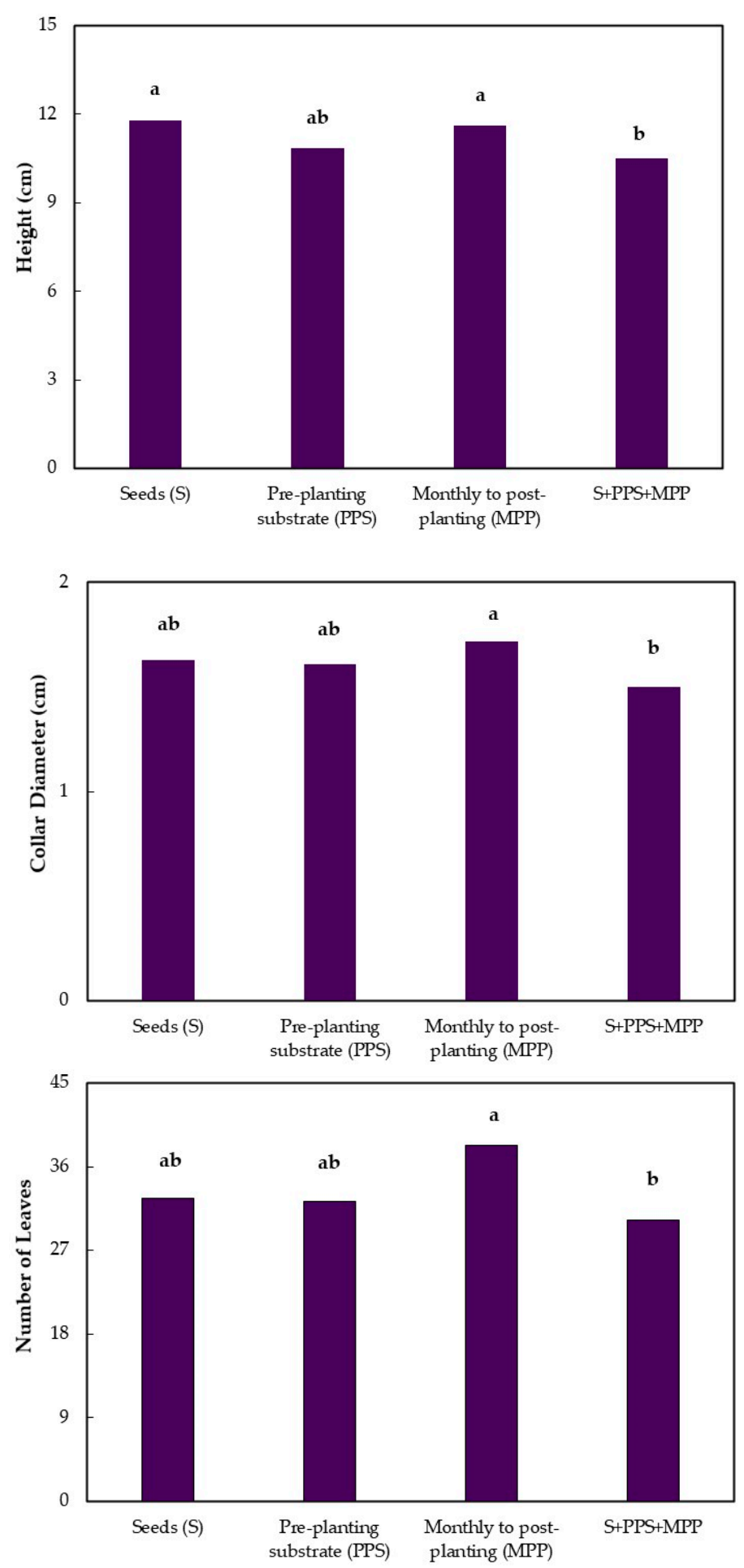

Figure 1. Height, collar diameter, and number of leaves of jabuticaba seedlings (Myrciaria cauliflora) submitted to different application modes of Trichoderma seven months after seedling emergence. Means followed by the same lowercase letters in the columns do not differ by Tukey's Test $(p \leq 0.01)$.

In the evaluation at 13 months after emergence, no difference was observed between the treatments and the control by the Dunnett test. There was a significant difference between treatments for the application mode factor in the seedling height and collar diameter. Seedling height was higher when Trichoderma isolates were applied on the preplanting substrate compared to the monthly applications on the post-planting substrate and the combination of the three application modes (Figure 2), with increases of $10 \%$ and $11.8 \%$ 
in relation to these two treatments, respectively. The Trichoderma isolates applied monthly in the post-planting substrate increased the collar diameter, compared to the combined treatments (Figure 2).
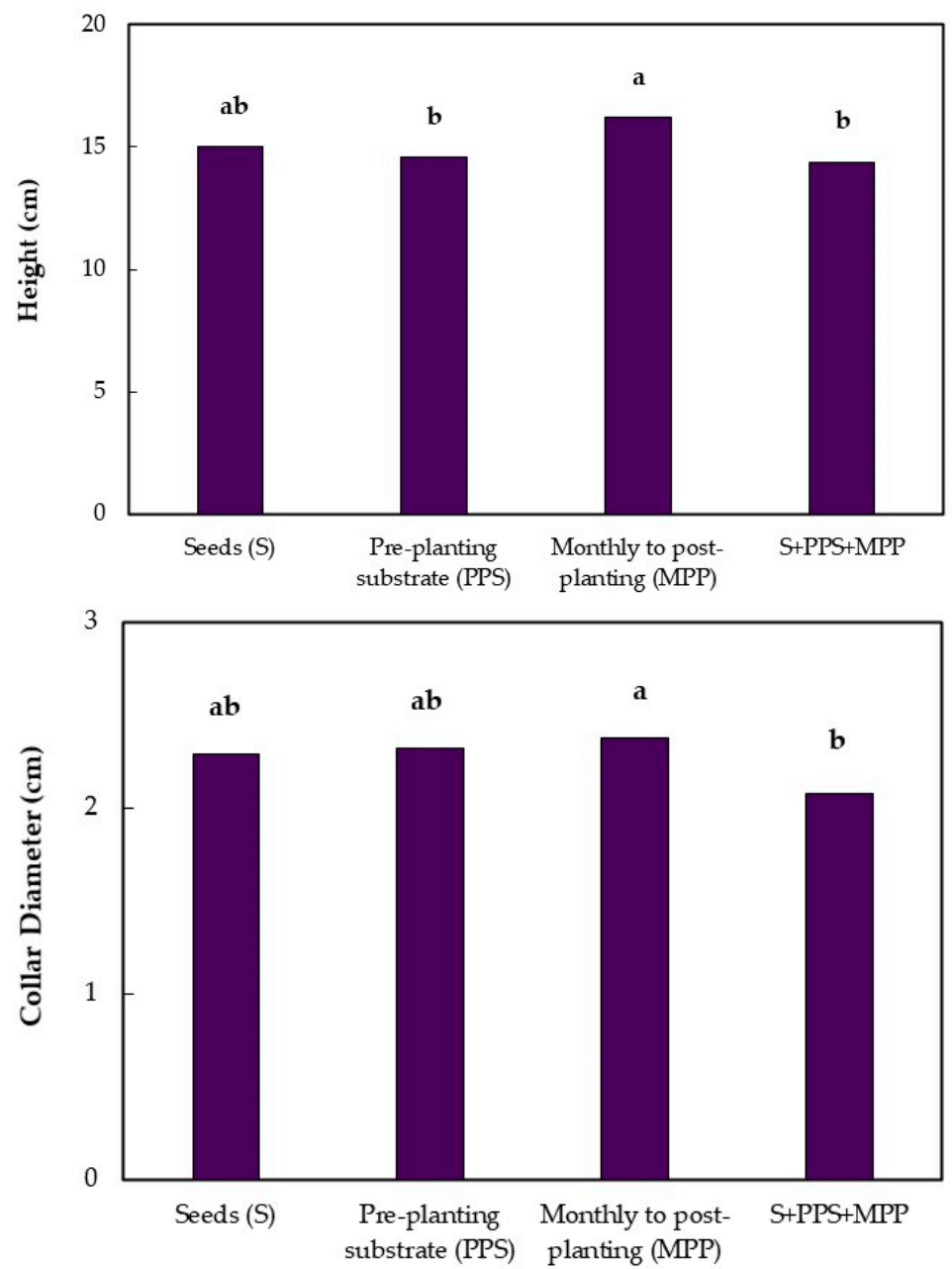

Figure 2. Height and collar diameter of jabuticaba seedlings (Myrciaria cauliflora) submitted to different application modes of Trichoderma 13 months after seedling emergence. Means followed by the same lowercase letters in the columns do not differ by Tukey's Test $(p \leq 0.01)$.

\section{Discussion}

The promising results obtained from the application of Trichoderma at two and, mainly, at four months after the emergence of jabuticaba seedlings suggest that, in this species, such isolates can positively influence growth and development in the initial months of the seedling production of this species.

The height of jabuticaba seedlings at two and four months after seedling emergence had an increase provided by six treatments compared to the control. The application of Trichoderma on guava seedlings (Psidium guajava), a species of the same botanical family as jabuticaba (Myrtaceae), did not generate significant results for height 30 days after planting [33]; however, the decrease in height increment was associated with the infestation of nematodes in the substrate, which consequently caused a decline in plant development due to deformations in the root system, with decreased absorption of water and nutrients and not to Trichoderma itself. Uvaia plants (Eugenia pyriformis), Myrtaceae, treated with two products based on Trichoderma spp., had an increase in height ranging from 8 to $20 \mathrm{~cm}$ compared to the control [34]. A significant result for height was also obtained in seedlings of Enterolobium schomburgkii, a forest species of the Amazonian, during the first two months with the application of Trichoderma [12]. 
Two months after emergence, the treatments did not influence the collar diameter of jabuticaba seedlings, a fact that may be related to the initial increase in height growth, elongating the stem in search of luminosity, emission, and leaf expansion to later invest in diameter growth [35]. However, after four months, 15 treatments increased this variable compared to the control. In this evaluation, the T. asperellum Tam01 and Tam03 e, Trichoderma sp. Tc, increased the collar diameter, regardless of the application mode used, indicating that, if the objective is to increase this variable, these three isolates could be used in any application mode tested. It is possible that the increase in collar diameter is associated with the positive response in the increase in the number of leaves provided by Trichoderma isolates.

The collar diameter is the variable that best infers plant performance after planting, therefore higher values are usually related to an abundant root system and thus benefits the development of plants under competitive conditions [36]. It is an appropriate variable to be considered when one wants to know the quality of seedlings, different from the height, which can indicate the planting of non-rusticized seedlings (not resistant to adverse field conditions), increasing plant mortality in the field, since the environmental variations influence strongly on the height $[37,38]$.

Additionally, the collar diameter can be an indicator of net photosynthesis, as the increase depends on the exchange activity, which is stimulated by carbohydrates produced by photosynthesis and hormones transported from the apical aerial parts [39], which is also related to the increase in the number of leaves provided by Trichoderma isolates.

Seedlings with a small collar diameter and high heights are considered of lower quality than those smaller in height and with a larger collar diameter [40]. Seedlings with larger collar diameters show a better balance of shoot growth [38].

Different effects on the collar diameter promoted by the use of Trichoderma have been reported in many works. The application of Trichoderma on red angico seedlings (Parapiptadenia rigida) increased the collar diameter, compared to the control, 60 days after emergence [41]. The use of different Trichoderma isolates in peach palm (Bactris gasipaes) had a beneficial effect on the collar diameter [42]. Different modes of application of this fungus on açaí palm (Euterpe oleracea) provide increases in collar diameter [5]. Ten isolates of Trichoderma spp., from the Amazon region applied in the treatment of solitary açaí (Euterpe precatoria), did not influence the collar diameter [43]. The same Trichoderma isolates tested in this work were evaluated on African mahogany (Khaya ivorensis) and did not increase the collar diameter of the seedling [13].

The number of leaves was positively influenced by the treatments and, at four months, it was the variable with the highest number of treatments that differed from the control (18 out of 20 tested). The number of leaves is an excellent indicator of seedling qualities and works directly on the accumulation of plant biomass [44].

Positive results from the application of Trichoderma on the number of leaves found for jabuticaba have also been observed in other species. In Eucalyptus camaldulensis plants, Trichoderma caused an increase of $110 \%$ in the number of leaves, 95 days after planting [45]. When the seedlings of Citrus sp. received the application of Trichoderma in the substrate, there was a stimulus in the production of leaves, with a greater presence of chlorophyll and with a greater development of the main and secondary roots in the field [46]. The evaluation of the quality of the seedlings of South American yellow poinciana (Peltophorum dubium) showed a difference in the number of leaves per seedling, when the Trichoderma isolate was applied by watering the substrate at the time of sowing [47]. E. oleracea plants treated with Trichoderma spp. showed an increase of $9 \%$ in the number of leaves, with an increase in chlorophyll content as well, in relation to the control [48]. However, in seedlings of the fruit tree Annona muricata, treatment with Trichoderma spp. did not increase the number of leaves on the plants compared to the control [49].

The difference found between treatments in the interaction of factors for the height and collar diameter at two and four months after emergence show that the mode of application and the Trichoderma isolate influence the growth promotion of jabuticaba seedlings. The use 
of Trichoderma species on passionflower (Passiflora sp.) seedlings showed different results for the application modes (seed treatment, foliar application, and incorporation of rice grains colonized by Trichoderma spp. to the substrate) and for the species used [50].

The promising results found four months after emergence indicate that, in jabuticaba, the Trichoderma isolates evaluated in this work may have found the most satisfactory conditions in this period for their development and, consequently, to express their potential in promoting plant growth. The fungi T. asperellum Tam03 and T. asperellum Tam01 stood out, with the largest number of treatments that positively influenced the analyzed variables. The significant results at four months of age are practical effects for plant growth, because, if we relate to the fact that the emergence of jabuticaba seedlings occurs between 30 and 50 days after sowing [51], with a slow development of seedlings, this phase is critical for the culture, and the fact that the fungi increased their growth in this initial phase is promising. Furthermore, even if Trichoderma had not promoted growth during this period, the use of the biological agent would still be interesting, as it exerts its main role as a control agent, protecting the seeds during this long period of permanence in the soil against the attack of phytopathogens that were present in the substrate. The efficiency of Trichoderma's mechanisms of action depends on specific biotic and abiotic factors such as temperature, humidity, $\mathrm{pH}$, and nutrient availability [52].

At 7 and 13 months after emergence, no difference was observed between treatments and control. However, there was a difference between treatments for the mode of application factor, demonstrating that biological agents can also be influenced by the way it is applied to plants, interfering with its performance in the production of jabuticaba seedlings. The use of the same Trichoderma isolates evaluated in this work were tested to promote the growth of ipe (Handroanthus sp.) and, at 12 months after planting, no effect on the analyzed variables was observed either [4].

The growth promotion caused by Trichoderma spp. has already been reported in plants belonging to many botanical families. Different behavior among isolates of Trichoderma spp. was observed in the development of herbaceous and woody plants by different authors [4,53-56]. The mechanisms of action of plant growth-promoting fungi are specific and may vary depending on the environment, substrate, nutrient availability, and interference from other microorganisms [54].

Considerable growth-promoting effects were observed in eucalyptus-lemon (Corymbia citriodora) seedlings inoculated with different Trichoderma asperelloides isolates [57]. Seedlings produced by eucalyptus seeds and clones (Eucalyptus camaldulensis, Eucalyptus urophylla, and Eucalyptus grandis) treated with Trichoderma harzianum showed a $43 \%$ increase in plant height, with applications in the substrate of clonal seedlings [55].

The application of Trichoderma isolates to rubber tree (Hevea brasiliensis) seedlings, six months after planting, increased the collar diameter $(13.8 \%)$ and the number of leaves (71.4\%) compared to the control [58]. The stem of crack willow (Salix fragilis) seedlings cultivated with Trichoderma spp. increased by 40\% [59]. Seedlings of camboim (Myrciaria tenella), a plant of the same family as the jabuticaba, treated with Trichoderma, did not differ in height compared to the control [60].

Treatments with Trichoderma spp. may show unevenness due to the response of the variables and species used and show variability between strains with respect to biocontrol activities, the performance of activity against hosts, physiological and biochemical properties, and ecological and environmental adaptability, determining its performance as a bioprotector and growth promoter in plants [61].

The climatic conditions that affect the plants can also interfere with the ideal conditions for developing Trichoderma. Meteorological data in the region during the evaluation of the work show that, from six months after emergence, precipitation decreased in relation to previous months. In May 2019 (5th month after emergence), precipitation was $606 \mathrm{~mm}$, $156 \mathrm{~mm}$ in June, and $49 \mathrm{~mm}$ in July [62].

The host plant must be considered an additional cause of modification, being directly associated with different responses presented by Trichoderma in the field; thus, the use 
of different Trichoderma isolates in different varieties or cultivars can generate different responses in developmental variables [63].

The benefits promoted to several plant species by Trichoderma isolates is notorious. This genus of fungi can promote plant shoot growth and produce auxins and metabolites that favor root development [64]. Phosphate solubilization is a mechanism of Trichoderma species to promote plant growth [58,65], although there are other mechanisms to increase plant growth and production [58].

Studies describing the ability of Trichoderma to promote plant growth, seed germination, and the stimulation of plant defenses against pathogens and environmental stresses are frequent. The efficiency of Trichoderma as biocontrol and biostimulation agents should be increasingly researched, based on the selection of the best strains [66], or the combination of strains aimed at the greater benefits of this genus of fungi in the plant production of each crop [53]. The development of viable commercial products based on Trichoderma is a promising approach for a more sustainable agriculture [67].

\section{Conclusions}

The application of Trichoderma spp. promoted the growth of jabuticaba seedlings up to four months after emergence. The isolate of Trichoderma asperellum Tam03 and the method of application via seeds were the treatments that most influenced the analyzed variables at four months, a period in which the greatest effects of fungi on the growth of jabuticaba seedlings were observed.

We recommend future studies to evaluate leaf area, chlorophyll content, dry mass, and nutrients, as well as the application of Trichoderma combined with plant nutrition through organic fertilization aimed at the ecological cultivation of this species of importance to human health and nutrition.

Author Contributions: Conceptualization, D.C.L. and T.A.V.; methodology, M.N.B., N.F.B., W.N.d.S., T.A.V., D.C.L. and C.A.F.; software, D.C.L., T.A.V. and C.A.F.; validation, D.C.L., C.A.F. and T.A.V.; formal analysis, W.N.d.S., N.F.B., T.A.V., D.C.L. and C.A.F.; investigation, M.N.B., W.N.d.S., N.F.B., T.A.V., D.C.L. and C.A.F.; resources, D.C.L., T.A.V. and C.A.F.; data curation, M.N.B., W.N.d.S., N.F.B., T.A.V., D.C.L. and C.A.F.; writing - original draft preparation, M.N.B., N.F.B., W.N.d.S., T.A.V. and D.C.L.; writing-review and editing, D.C.L., T.A.V. and C.A.F.; visualization, D.C.L. and T.A.V.; supervision, D.C.L. and T.A.V.; project administration, D.C.L.; funding acquisition, D.C.L. and T.A.V. All authors have read and agreed to the published version of the manuscript.

Funding: This work was supported by the Institutional Scientific Initiation Scholarship Program2018 PIBIC/UFOPA and the APC was funded by PROPPIT/Federal University of Western Pará through Edital 03/2021 (Programa de Apoio à Produção Científica Qualificada).

Data Availability Statement: The data presented in this study are available in the text, figures, and tables.

Acknowledgments: We would like to thank the anonymous reviewers for their suggestions and constructive comments on the manuscript.

Conflicts of Interest: The authors declare no conflict of interest.

\section{References}

1. Mohamed, A.A.; Salah, M.M.; El-Dein, M.M.Z.; El-Hefny, M.; Ali, H.M.; Farraj, D.A.A.; Hatamleh, A.A.; Salem, M.Z.M.; Ashmawy, N.A. Ecofriendly bioagents, parthenocissus quinquefolia, and Plectranthus neochilus extracts to control the early blight pathogen (Alternaria solani) in tomato. Agronomy 2021, 11, 911. [CrossRef]

2. Solis-Palacios, R.; Hernández-Ramírez, G.; Salinas-Ruiz, J.; Hidalgo-Contreras, J.V.; Gómez-Merino, F.C. Effect and compatibility of phosphite with Trichoderma sp. isolates in the control of the Fusarium species complex causing pokkah boeng in sugarcane. Agronomy 2021, 11, 1099. [CrossRef]

3. de Sousa, W.N.; Brito, N.F.; Felsemburgh, C.A.; Vieira, T.A.; Lustosa, D.C. Evaluation of Trichoderma spp. isolates in cocoa seed treatment and seedling production. Plants 2021, 10, 1964. [CrossRef] [PubMed]

4. Santos, M.F.; Santos, L.E.; Costa, D.L.; Vieira, T.A.; Lustosa, D.C. Trichoderma spp. on treatment of Handroanthus serratifolius seeds: Effect on seedling germination and development. Heliyon 2020, 6, e04044. [CrossRef] [PubMed] 
5. Campos, B.F.; Araújo, A.J.C.; Felsemburgh, C.A.; Vieira, T.A.; Lustosa, D.C. Trichoderma contributes to the germination and seedling development of açaí Palm. Agriculture 2020, 10, 456. [CrossRef]

6. Poveda, J.; Hermosa, R.; Monte, E.; Nicolás, C. Trichoderma harzianum favours the access of arbuscular mycorrhizal fungi to non-host Brassicaceae roots and increases plant productivity. Sci. Rep. 2019, 9, 11650. [CrossRef]

7. Mohamed, H.A.L.A.; Haggag, W.M. Biocontrol potential of salinity tolerant mutants of Trichoderma harzianum against Fusarium oxysporum. Braz. J. Microbiol. 2006, 37, 181-191. [CrossRef]

8. Miceli, A.; Moncada, A.; Vetrano, F. Use of microbial biostimulants to increase the salinity tolerance of vegetable transplants. Agronomy 2021, 11, 1143. [CrossRef]

9. Chagas, L.F.B.; Chagas Junior, A.F.; Soares, L.P.; Fidelis, R.R. Trichoderma na promoção do crescimento vegetal. Rev. Agric. Neotrop. 2017, 4, 97-102. [CrossRef]

10. Pedro, E.A.S.; Harakava, R.; Lucon, C.M.M.; Guzzo, S.D. Promoção do crescimento do feijoeiro e controle da antracnose por Trichoderma spp. Pesqui. Agropecúaria Bras. 2012, 47, 1589-1595. [CrossRef]

11. Silva, V.N.; Guzzo, S.D.; Lucon, C.M.M.; Harakava, R. Promoção de crescimento e indução de resistência à antracnose por Trichoderma spp. em pepineiro. Pesqui. Agropecuária Bras. 2011, 46, 1609-1618. [CrossRef]

12. Santos, M.F.; Costa, D.L.; Vieira, T.A.; Lustosa, D.C. Effect of Trichoderma spp. fungus for production of seedlings in Enterolobium schomburgkii (Benth.) Benth. AJCS 2019, 13, 1706-1711.

13. Lustosa, D.C.; Araújo, A.J.C.; Campos, B.F.; Vieira, T.A. Trichoderma spp. and its effects on seeds physiological quality and seedlings development of African mahogany. Rev. Bras. Cienc. Agrar 2020, 15, e5843. [CrossRef]

14. Orhan, E.; Esitken, A.; Ercisli, S.; Turan, M.; Sahin, F. Effects of plant growth promoting rhizobacteria (PGPR) on yield, growth and nutrient contents in organically growing raspberry. Sci. Hortic. 2006, 111, 38-43. [CrossRef]

15. Aguiar, A.R.; Aguiar, D.; Tedesco, S.B.; Silva, A.C.F. Efeito de metabólitos produzidos por Trichoderma spp. sobre o índice mitótico em células das pontas de raízes de Allium cepa. Biosci. J. 2015, 31, 934-940. [CrossRef]

16. Oliveira, A.G.; Chagas Junior, A.F.; Santos, G.R.; Miller, L.O.; Chagas, L.F.B. Potencial de solubilização de fosfato e produção de AIA por Trichoderma spp. Rev. Verde Agroecol. Desenvolv. Sustentável 2012, 7, 149-155.

17. Germida, J.J.; Walley, F.L. Plant growth-promoting rhizobacteria alter rooting patterns and arbuscular mycorrhizal fungi colonization of field-grown spring wheat. Biol. Fertil. Soils 1996, 23, 113-120. [CrossRef]

18. Bononi, L.; Chiaramonte, J.B.; Pansa, C.C.; Moitinho, M.A.; Melo, I.S. Phosphorus-solubilizing Trichoderma spp. from Amazon soils improve soybean plant growth. Sci. Rep. 2020, 10, 2858. [CrossRef]

19. Baptistella, C.S.L.; Coelho, P.J. Jabuticaba do quintal para produção de mercado. Análises Indic. Agronegócio 2019, 14, 1-10.

20. Boari Lima, A.J.; Duarte Corrêa, A.; Carvalho Alves, A.P.; Patto Abreu, C.M.; Dantas-Barros, A.M. Caracterização química do fruto jabuticaba (Myrciaria cauliflora Berg) e de suas frações. Arch. Latinoam. Nutr. 2008, 58, 416-421.

21. Oliveira, A.L.; Brunini, M.A.; Salandini, C.A.R.; Bazzo, F.R. Caracterização tecnológica de jabuticabas 'Sabará' provenientes de diferentes regiões de cultivo. Rev. Bras. Frutic. 2003, 25, 397-400. [CrossRef]

22. Lorenzi, H. Arvores Brazileiras: Manual de Identificação e Cultivo de Plantas Arbóreas Nativas do Brazil, 1st ed.; Instituto Plantarum: Nova Odessa, Brazil, 2009; 384p.

23. Wu, S.B.; Dastmalchi, K.; Long, C.; Kennelly, E.J. Metabolite profiling of jaboticaba (Myrciaria cauliflora) and other dark-colored fruit juices. J. Agric. Food Chem. 2012, 60, 7513-7525. [CrossRef] [PubMed]

24. Ascheri, D.P.R.; Ascheri, J.L.R.; Carvalho, C.W.P. Caracterização da farinha de bagaço de jabuticaba e propriedades funcionais dos extrusados. Ciência Tecnol. Aliment. 2006, 26, 897-905. [CrossRef]

25. Alisson, E. Extrato da Casca de Jabuticaba Promove Efeitos Benéficos à Saúde. 2018. Available online: https://www. unicamp.br/unicamp/ju/noticias/2018/11/06/extrato-da-casca-de-jabuticaba-promove-efeitos-beneficos-saude (accessed on 28 March 2021).

26. Silva, M.C.; Souza, V.B.; Thomazini, M.; Silva, E.R.; Smaniotto, T.; Carvalho, R.A.; Genovese, M.I.; Favaro-Trindade, C.S. Use of the jabuticaba (Myrciaria cauliflora) depulping residue to produce a natural pigment powder with functional properties. LWT-Food Sci. Technol. 2014, 55, 203-209. [CrossRef]

27. Santos, D.T.; Veggi, P.C.; Meireles, M.A.A. Extraction of antioxidant compounds from Jabuticaba (Myrciaria cauliflora) skins: Yield, composition and economical evaluation. J. Food Eng. 2010, 101, 23-31. [CrossRef]

28. Baldin, J.C.; Michelin, E.C.; Polizer, Y.J.; Rodrigues, I.; Godoy, S.H.S.; Fregonesi, R.P.; Pires, M.A.; Carvalho, L.T.; Fávaro-Trindade, C.S.; Lima, C.G.; et al. Microencapsulated jabuticaba (Myrciaria cauliflora) extract added to fresh sausage as natural dye with antioxidant and antimicrobial activity. Meat Sci. 2016, 118, 15-21. [CrossRef]

29. Cavalcanti, R.N.; Veggi, P.C.; Meireles, M.A.A. Supercritical fluid extraction with a modifier of antioxidant compounds from jabuticaba (Myrciaria cauliflora) byproducts: Economic viability. Procedia Food Sci. 2011, 1, 1672-1678. [CrossRef]

30. Carlos, D.A.I.; Martorano, L.G.; Gaspar, A.B.S.; Franco, I.M.; Silva, R. Uma aplicação na geociência da termografia infravermelho para diagnosticar padrões térmico-hídricos em solos com culturas irrigadas por potes de argila no oeste do Pará, Amazônia. Anuário Inst. Geociências 2021, 44, 39655. [CrossRef]

31. Alfenas, A.C.; Mafia, R.G. Métodos em Fitopatologia, 1st ed.; UFV: Viçosa, Brazil, 2007; 382p.

32. Silva, F.A.S.; Azevedo, C.A.V. The Assistat Software Version 7.7 and its use in the analysis of experimental data. Afr. J. Agric. Res. 2016, 11, 3733-3740. 
33. Silva, A.A.; Souza, I.V.B.; Porto, J.S.; São José, A.R. Utilização de fungos benéficos na formação de mudas de goiabeira em solos infestados com nematoides. Pesqui. Agrárias Ambient. 2020, 8, 178-184. [CrossRef]

34. Soldan, A.M. Desenvolvimento E Estado Nutricional de Mirtáceas Sob O Efeito de Trichoderma spp. E Fosfato Natural. Master's Thesis, Universidade Estadual do Centro-Oeste, Guarapuava, Brazil, 2014; p. 70.

35. Imaña-Encinas, J.; Silva, G.F.; Pinto, J.R.R. Idade E Crescimento Das Árvores; Universidade de Brasília: Brasília, Brazil, 2005; 43p.

36. Ritchie, G.A.; Landis, T.D.; Dumroese, R.K.; Haase, D.L. Assessing Plant Quality; US Department of Agriculture Forest Service: Washington, DC, USA, 2010; pp. 17-81.

37. Rudek, A.; Garcia, F.A.O.; Bandeira, F.S.P. Avalição da qualidade de mudas de Eucalipto pela mensuração da área foliar com o uso de imagens digitais. Enciclopédia Biosf. 2013, 9, 3775-3787.

38. Carneiro, J.G.A. Produção E Controle de Qualidade de Mudas Florestais; UFPR/PUPEF: Curitiba, Brazil, 1995; 451p.

39. Paiva, L.C.; Guimarães, R.J.; Souza, C.A.S. Influência de diferentes níveis de sombreamento sobre o crescimento de mudas de cafeeiro (Coffea arabica L.). Ciência Agrotecnol. 2003, 27, 134-140. [CrossRef]

40. Sturion, J.A.; Graçã, L.R.; Antunes, J.B.M. Produção de Mudas de Espécies de Rápido Crescimento Por Pequenos Produtores; Embrapa Florestas: Colombo, Brazil, 2000; 20p.

41. Missio, E.L.; Muniz, M.F.B.; Brum, D.L.; Schultz, C.P.; Cargnelutti Filho, A. Produção de mudas de Parapiptadenia rigida pelo tratamento de sementes com Trichoderma (Hypocreales) e polímero. Cad. Pesqui. 2018, 30, 21-32.

42. Fuzitani, E.J.; Santos, A.F.; Damatto Jr, E.R.; Nomura, E.S.; Kalil Filho, A.N. Inoculation methods, aggressiveness of isolates and resistance of peach palm progenies to Phytophthora palmivora. Summa Phytopathol. 2018, 44, 213-217. [CrossRef]

43. Costa, K.K.; Rufino, C.P.B.; Macedo, P.E.F.; Nogueira, S.R. Uso de Trichoderma spp. para o controle da Antracnose em Euterpe precatoria no Acre. In Anais, II Seminário da Embrapa Acre de Iniciação Científica E Pós-Graduação Embrapa; Embrapa: Rio Branco, Brazil, 2020; pp. 9-15.

44. Câmara, C.A.; Endres, L. Desenvolvimento de mudas de duas espécies arbóreas: Mimosa caesalpiniifolia Benth. e Sterculia foetida L. sob diferentes níveis de sombreamento em viveiro. Floresta 2008, 38, 43-51. [CrossRef]

45. Azevedo, G.B.; Novaes, Q.S.; Azevedo, G.T.O.S.; Silva, H.F.; Rocha Sobrinho, G.G.; Novaes, A.B. Efeito de Trichoderma spp. no crescimento de mudas clonais de Eucalyptus camaldulensis. Sci. For. 2017, 45, 343-352. [CrossRef]

46. Prates, H.S.; Cesmik, R.; Ferraz, J.M.G. Trichoderma spp. No Controle de Doenças de Plantas; Embrapa: Brasília, Brazil, 2006.

47. Junges, E.; Muniz, M.F.; Mezzomo, R.; Bastos, B.; Machado, R.T. Trichoderma spp. na produção de mudas de espécies florestais. Florest. Ambiente 2016, 23, 237-244. [CrossRef]

48. Santos, G.R.; Ferreira, W.X.; Mendes, T.O.; Machado, R.C.L.; Silva, G.B. Indução de crescimento em mudas de açaizeiro com o fungo Trichoderma asperellum. In Anais, III Congresso Internacional das Ciências Agrárias; Instituto Internacional Despertando Vocações: Recife, Brazil, 2018; p. 9.

49. Almeida, C.L.S. Uso de Trichoderma spp. Na Emergência de Plântulas de Gravioleira E Produção de Mudas em Diferentes Substratos E Ambientes. Master's Thesis, Universidade Federal de Campina Grande, Pombal, Portugal, 2017.

50. Pereira, G.V.N. Promoção do Crescimento de Mudas de Maracujazeiro Inoculadas Com Trichoderma spp. Master's Thesis, Universidade Estadual do Sudoeste da Bahia, Vitória da Conquista, Brazil, 2012.

51. Suguino, E.; Martins, A.N.; Turco, P.H.N.; Cividanes, T.M.S.; Faria, A.M. A cultura da jabuticabeira. Pesqui. Tecnol. $2012,9,1-7$.

52. Nieto-Jacobo, M.F.; Steyaert, J.M.; Salazar-Badillo, F.B.; Nguyen, D.V.; Rostás, M.; Braithwaite, M.; Mendoza-Mendoza, A. Environmental growth conditions of Trichoderma spp. affects indole acetic acid derivatives, volatile organic compounds, and plant growth promotion. Front. Plant Sci. 2017, 8, 102. [CrossRef]

53. Chen, D.; Hou, Q.; Jia, L.; Sun, K. Combined use of two Trichoderma strains to promote growth of Pakchoi (Brassica chinensis L.). Agronomy 2021, 11, 726. [CrossRef]

54. Machado, D.F.M.; Tavares, A.P.; Lopes, S.J.; Silva, A.C.F. Trichoderma spp. na emergência e crescimento de mudas de Cambará (Gochnatia polymorpha (Less.) Cabrera). Rev. Árvore 2015, 39, 167-176. [CrossRef]

55. Carvalho Filho, M.R.; Mello, S.C.M.; Santos, R.P.; Menêzes, J.E. Avaliação de Isolados de Trichoderma Na Promoção de Crescimento, Produção de Ácido Indolacético In Vitro e Colonização Endofítica de Mudas de Eucalipto; Embrapa Recursos Genéticos e Biotecnologia: Brasília, Brazil, 2008; 16p.

56. Donoso, E.; Lobos, G.A.; Red, N. Efeito de Trichoderma harzianum e composto no crescimento de mudas de Pinus radiata em viveiro. Bosque 2008, 29, 52-57. [CrossRef]

57. Steffen, G.P.K.; Maldaner, J.; Steffen, R.B.; Saldanha, C.W.; Peccatti, A. Trichoderma asperelloides promove crescimento inicial em mudas de Corymbia citriodora. Enciclopédia Biosf. 2019, 16, 1699. [CrossRef]

58. Promwee, A.; Issarakraisila, M.; Intana, W.; Chamswarng, C.; Yenjit, P. Phosphate solubilization and growth promotion of rubber tree (Hevea Braziliensis Muell. Arg.) by Trichoderma strains. J. Agric. Sci. 2014, 6, 8-20.

59. Adams, P.; De-Leij, F.A.A.M.; Lynch, J.M. Trichoderma harzianum rifai 1295-22 mediates growth promotion of crack willow (Salix fragilis) saplings in both clean and metal-contaminated soil. Microb. Ecol. 2007, 54, 306-313. [CrossRef]

60. Rolim, J.M.; Rabuske, J.E.; Savian, L.G.; Walker, C.; Brun, T.; Muniz, M.F.B. Trichoderma harzianum como promotor de crescimento de Peltophorum dubium. In Anais, 12 Salão Internacional de Ensino, Pesquisa e Extensão da Unipampa; Unipampa: Bage, Brazil, 2017.

61. Silva, P.R.Q. Transformação de Trichoderma harzianum Com Genes Egfp E Tubulina. Master's Thesis, Universidade de Brasília, Brasília, Brazil, 2000. 
62. Inmet-Instituto Nacional de Meteorologia. Estação Meteorológica de Observação de Superfície Automática; Inmet: Brasília, Brazil, 2019.

63. Medeiros, F.H.V.; Guimarães, R.A.; Silva, J.C.P.; Cruz-Magalhães, V.; Silva, J.T. Trichoderma: Interações e estratégias. In Trichoderma: Uso Na Agricultura; Meyer, M.C., Mazaro, S.M., Silva, J.C., Eds.; Embrapa Soja: Brasília, Brazil, 2019 ; pp. $219-234$.

64. Vinale, F.; Sivasithamparam, K.; Ghisalberti, E.L.; Marra, R.; Barbetti, M.J.; Li, H.; Woo, S.L.; Lorito, M.A. Novel role for Trichoderma secondary metabolites in the interactions with plants. Physiol. Mol. Plant Pathol. 2008, 72, 80-86. [CrossRef]

65. Jaeger, N.; La Providencia, I.E.; Boulois, H.D.; Declerck, S. Trichoderma harzianum might impact phosphorus transport by arbuscular mycorrhizal fungi. FEMS Microbiol. Ecol. 2011, 77, 558-567. [CrossRef]

66. Monte, E.; Bettiol, W.; Hermosa, R. Trichoderma e seus mecanismos de ação para o controle de doenças de plantas. In Trichoderma: Uso Na Agricultura; Meyer, M.C., Mazaro, S.M., Silva, J.C., Eds.; Embrapa Soja: Brasília, Brazil, 2019; pp. $181-199$.

67. Abdullah, N.S.; Doni, F.; Mispan, M.S.; Saiman, M.Z.; Yusuf, Y.M.; Oke, M.A.; Suhaimi, N.S.M. Harnessing Trichoderma in Agriculture for Productivity and Sustainability. Agronomy 2021, 11, 2559. [CrossRef] 